\title{
The Transformation of Ice-Candy-Man: Account of Partition Trauma in Cracking India
}

\author{
Archana Katariya* and Priyanka Chaudhary \\ Department of Languages, Manipal University Jaipur, 303007 Rajasthan, India
}

\begin{abstract}
This article aims to unveil the capricious transformation of the key figure, Ice-CandyMan (named Dilnawaz) and the riotous traumatic impact of the Partition of India on his personality in Cracking India. The most arousing, poignant, efficacious figure Ice-CandyMan of Bapsi Sidhwa's magnum opus Cracking India traps the mind of the readers. Sidhwa, the original mark and a victim of the Partition in 1947, had sensed the brutal incidents which impaled her heart with pathos and enforced her to pen it down by presenting vivacious, colorful characters with autobiographical touches. The Ice-Candy-Man appears with a different disguise each time. Why did Sidhwa characterize him in such a specific and dynamic manner? His gestures, speech and even his transition stages and his every next footstep are the symbols and metaphors of the changing society during the traumatic events of Partition - they denote how an individual turns his course of life. His act of transformation is the core to unlocking Sidhwa's magical world. Without analyzing the Ice-Candy-Man, all endeavors to interpret Sidhwa's messages are futile.
\end{abstract}

ARTICLE INFO

Article history:

Received: 7 April 2020

Accepted: 23 August 2020

Published: 25 December 2020

DOI: https://doi.org/10.47836/pjssh.28.4.26

E-mail addresses:

archanasatish7973@gmail.com (Archana Katariya)

priyanka.chaudhary@jaipur.manipal.edu (Priyanka Chaudhary)

*Corresponding author
Keywords: Bapsi Sidhwa, Cracking India, Ice-Candy-

Man, Indian society, partition, transformation, trauma

\section{INTRODUCTION}

India was under the rule of the British Crown from 1858 to 1947 , eventually gaining independence on August 15, 1947 at the cost of getting divided into two 
separate nations - India and Pakistan. The partition of India saw massacres and much bloodshed because the people were not mentally prepared to leave their homeland and families. What led to the partition was not so much the country's independence as it was the Colonizers' divide and rule policy. There are various fundamental assumptions on the division of the subcontinent by many authors. Historians' opinions differ on why the partition actually took place, but it is a general view that the 'divide and rule' policy of the British was predominantly responsible. Cracking India is one of its kind which represents Parsi-Pakistani perspective of Partition by a diasporic PakistaniAmerican female author.

\section{The Fundamental Notions behind the Partition of India}

India got independence at the cost of its partition. According to theorists, after the Britishers' declaration of freedom for India, Muslims were not in favor of this autonomy - they wanted a separate nation for themselves because they felt that they would be in danger in independent India. Muslims and Hindus, they emphasized, had diverse cultures, traditions, languages and lifestyles. Majid and Hamid (2014) talked about the Muslim League,

...which alone had the right to represent the Muslims of India. They have always taken it for granted mistakenly that Muslims are a minority. He said Muslims are a nation by any definition of a nation. Hindus and Muslims belong to two religions, philosophies, social customs and literature. They neither inter-marry nor inter-dine and belong to different civilizations based on conflicting ideas and conceptions; their concepts of life are different. As such, they must have their homeland, their territory and their state. (Majid \& Hamid, 2014, p. 180).

Shamsul Islam (2018), author of Muslims Against Partition of India, stated that in 1933, Choudhry Rahmat Ali, a Punjabi Muslim student at the University of Cambridge, first propounded the two-nation theory which later acquired a more concrete shape. This theory was later propagated by Muhammad Ali Jinnah, who went on to become the first Prime Minister of Pakistan. A more recent study (Sreenivas, 2017) had shown that Jinnah, wary of the political upheavals in the Hindu-majority India, required a separate homeland for the Muslim community while Nehru and Gandhi wanted a united India. The British wanted to separate themselves from this situation, which was why the date of Independence promised by Clement Attlee was declared one year prior. Proceeding with these ideas, Sreenivas (2017) had said,

With the clock ticking, in a radio address broadcast on June 3rd across British India, Nehru, Jinnah, Baldev Singh (as the representative of the Sikh community), and British Viceroy Lord Louis Mountbatten announced the plans for independence. These plans accepted that a partition must occur and that it would divide the provinces of Bengal 
in the east and Punjab in the northwest. The British civil servant assigned the monumental task of mapping this divide, Sir Cyril Radcliffe, was given just six short weeks to determine India and Pakistan's new borders. (Sreenivas, 2017, p. 13).

A study by Ahsan, the author of The Indus Saga and the Making of Pakistan,

the Indian subcontinent is made up of two civilizations, Indus and Indic (or Gangetic), and 'Indus has been one large, independent, politico-economic zone for the past countless centuries (...) [It has had] a rich and glorious cultural heritage of its own (...) [and is] a distinct and separate nation. (Ahsan, 1996, as cited in Roy, 2010, p. 14).

Some historians believe that imperialism tears the country into two parts. According to the study by Roy (2010), some of India's most notable historians like A. K. Banerjee, Sumit Sarkar, and Bipin Chandra believe that "this was a political strategy that the British had hit upon from the time of the Partition of Bengal in 1905 and had pursued with a single-minded zeal ever since" (Roy, 2010, p. 14). Both theories are more important and supported by many historians. Jalal stated:

The Partition was forced upon Jinnah by the Congress High Command in the penultimate phase of the British rule in India. According to her, the actual reason behind the Partition was not the scheme of the British but the constitutional tussle for greater representational power in the government that had gone on for close to four decades, between the Congress and the Muslim League. (Jalal, 1985, as cited in Roy, 2010, p. 14).

Hence, as we have seen, there are many prevalent theories propounded by different thinkers about the partition of India.

The terrors of partition left even the coming generations with wounds that can never be healed. Both soldiers and civilians experienced deeply traumatic events during the partition. Banyard said,

Ward and Carroll (1997), Safer, Christianson, Autry, and Osterlund (1998) and Mechanic, Resick, and Griffin (1998) presented discussions of ways in which trauma might lead to differences in the cognitive processing of events. Spiegel (1997) discussed links between dissociation and memories for traumatic events and Van Der Kolk and Fisler (1995) presented preliminary findings that suggested that traumatic memories might be stored in sensory-motor rather than narrative form, thus making them less accessible using conventional memory retrieval strategies. (Banyard, 2000, pp. 1-6).

Hunt (2010) said,

Many current theories of PTSD suggest that trauma is the result of 
enduring maladaptive responses which have impacted on the individual's autobiography or life story (e.g. Brewin \& Holmes, 2003; Brewin et al., 1996; Foa and Rothbaum, 1998; Nemeroff et al., 2006). Autobiographical memory is organised primarily around narrative structures, so if traumatic events impact on autobiographical memory, they inevitably impact on narrative and narrative development. (Hunt, 2010, p. 119).

When the partition of India was about to settle, the people filled with distress and trauma, as also narrated in Jadein ('Roots') by Ismat Chughtai and Toba Tek Singh by Saadat Hasan Manto. According to Urvasi Butalia, sectional violence settled with these movements on a large scale. Many migrants died of deficiencies, "malnutrition, contagious diseases" (Butalia, 1998, p. 3). For example, the figure varies from 200,000 (contemporary British figure) to two million (a later Indian estimate) (Butalia, 1998, p. 3). Butalia said about 75,000 women (Butalia, 1998, p. 3) were captured and raped by men known to them-men of the same religion, their neighbors. They were crossing the borders sometimes by car, bus, cart and train, and mostly on foot in large groups called kafilas.

The trauma of these haunting memories is so profound that many authors like Saadat Hasan Manto, Ismat Chughtai, Salman Rushdie, and Khushwant Singh have talked about it in their writings. Misra (2018, pp. 20-22) said that migration was not very easy-migrants struggle with their identity and face starvation, poverty and degradation in their new city or state. According to Shah (2018),

The partition of India hangs on the map of history like a chapter past the course of time- a diary of events with a partial vision of facts, uncertain data and the unavailable or half-narrated stories of individual experiences by seniors who were actual spectators to the painful trauma. (Shah, 2018, p. 150).

\section{METHODOLOGY}

The change in the persona, behaviour and attitude of Ice-Candy-Man was analysed through the critical interpretation of the novel by observing the impact on his psyche through postcolonial perspective. Documents published by the Governments of India and Pakistan had been used as a primary and secondary source like 'TwoNation Theory'.

\section{Representation of the Partition in 'Cracking India'}

Having witnessed the partition of India herself as a young girl, Bapsi Sidhwa was deeply affected by its events and portrays these images on the canvas of her masterpiece, Cracking India. She described the changing society from a Pakistani perspective. Sidhwa belonged to one of the smallest religious communities in the world-Parsis or Zoroastrianists. Said novel was first published by the title Ice-CandyMan (1988) in Pakistan; later, for publishing 
in America, the editor of the Milkweed Journal suggested that she changed the title to Cracking India.

Cracking India is a postcolonial novel on the partition of India. The partition cataclysm provoked the soul of indigenous. The lofty ideals of nationalism, solidarity and patriotism are pummelled in the light of communal turmoil which resulted in desolation. Socio-political harmony was seeming to be altering kaleidoscopically that time. Only religion has become the subjectivity and identity of the natives. Opportunisms, religious chauvinism and unjust oppression were observer by powerholders. It was not just partition but struggle for power and rule. Communal hysteria, holocaust, rehabilitation, uprootedness show vulnerability of structure of society in the name of nationhood. This disharmony and intolerance and hunger of power were transferred from the Britishers to the naive natives. This is 'doubleness'of belongingness and not-belonging and the natives started questioning as insider, outsider to their own people like East-West dichotomy. Hindu/Muslim binarism is seen as orient/occident dichotomy. National history and identity are shown through subverting collective trauma.

Sidhwa employed the character of Lenny, a polio-ridden Parsi girl, as an unbiased narrator for the purpose of innocent storytelling. Lenny was the shadow of Sidhwa, who witnessed India before its cracking. Zoroastrians were known for gelling well into new communities and remained unbiased. Thus, through Lenny, the author recounts the events objectively and without manipulating them. Lenny was an intelligent, precocious eight-yearold with a photographic memory. Gautam (2015, p. 519) said,

Lenny narrates the story of her changing world with sophistication and wonder and her child narrator status endows her account with reliability. Lenny does not report the happenings; She also interrogates various things, people, motives and emotions to comprehend their fullest meanings. The narrator of the child facilitates the author to look at things from an unbiased angle and place the narrative to multiple interpretations. (Gautam, 2015, p. 519).

As Sigmund Freud noted, creative writing, like daydreaming, is the window into the repressed feelings, thoughts and desires accumulated in the author's unconscious mind. Parapraxis and Freudian slips are also signs of the opening of the unconscious. Cracking India addresses history, memory, trauma, the predicament of women, and social crisis in the form of identity. Filmmaker Deepa Mehta's direction Earth 1947 was based on Cracking India. Visser (2011, p. 272) explained, "Trauma thus denotes the recurrence or repetition of the stressor event through memory, dreams, narrative and/or various symptoms known under the definition of Post-Traumatic Stress Disorder (PTSD).” Even today, many people's minds have not recovered from the traumatic memories of the partition. Ice- 
Candy-Man, Ayah and even little Lenny are all deeply affected by its events.

The Ice-Candy-Man (Dilnawaz) and his transformation is the key to unlocking Sidhwa's magical world that is Cracking India. Banerjee (2015, p. 142) said, "Bapsi Sidhwa's Ice-Candy-Man represents the story of Independence leading to Partition with the feminist point of view." Sidhwa's goal was to authentically portray the conditions of that period, and the character of Ice-Candy-Man was the perfect way to do it. Corresponding to this, Phogat and Attri (2013) said,

The portrayal of women by Sidhwa can be seen as a reaction against the negative portrayals of the local culture by the colonizers. Exploring the themes of struggles for independence, cultural conflict, displacement and feminism in their local settings was not accidental but a deliberate phenomenon. (Attri, 2013, p. 145).

At several instances, Ice-Candy-Man disguises himself and appears in front of the readers in different forms. From the beginning to the closing stages of the novel, he depicts various aspects of the fluctuating societal circumstances.

Postcolonial literature depicts the political and cultural subjugation of people in general and women in particular. Women have been oppressed by men in developing and colonized countries. As said by Virginia Woolf, women are viewed as sex objects and the second sex. Women's marginalization intensifies when they are commoditized through prostitution and pornography, as we also see in the case of Shanta. Concerning the role of feminism, Pandey (2003) said,

Feminism in literature refers to a mode that approaches a text with foremost concern for the nature of female experience in it. The fictional experience of characters, the rational, intuitional or imaginative capacity of an author, the experience implicit in language of structure that interrogates the cultural prescriptions, that subordinate and trivialize women and treat them as inferiors are the primary concerns of female fiction writers from a feminist perspective. (Pandey, 2003, p. 1).

From the beginning of the novel, Lenny narrates how Ayah is leered at by her admirers in a sexual manner.

Up and down they look at her. Holy men, masked in piety, shove aside their pretences to ogle her with lust...Ayah is chocolate brown and short. Everything about her is eighteen years old and round and plump... Full-brown cheeks, pouting mouth and smooth forehead curve to form a circle with her head... And, as if her looks were not stunning enough, she has a rolling, bouncing walk that agitates the globules of her buttocks under her cheap, colorful saris and the half spheres beneath her sariblouses. (Sidhwa, 2006, p. 13). 
Ice-Candy-Man, too, is attracted to Ayah and wants to marry her, but when the riots of the partition begin, every friend turns a foe and everyone starts being viewed as only a Hindu or a Muslim.

When Ice-Candy-Man finds the maimed bodies of his sisters on the train arriving from the other side of the border, he is deeply traumatised. Consequently, he abruptly takes on a completely different personality and exacts revenge on his love interest Shanta (Ayah) and starts seeing every friend of his as belonging to the other community. Ice-Candy-Man was a goodnatured person, but his twisted behaviour is an example of reaction formation in defense mechanisms. McLeod (2019) stated, "Defense mechanisms are psychological strategies that are unconsciously used to protect a person from anxiety arising from unacceptable thoughts or feelings." Ice-Candy-Man (Dilnawaz) first relates to Ayah's group-Sher Singh, Masseur, Hari, Butcher, Imam Din, Lenny and Ayah herself. 'Dilnawaz' means an attractive, loving and soothing heart. His name matches his personality perfectly and embellishes his character. Describing the character of IceCandy-Man, Bhaskar (2015, pp. 55-56) said, "Ice-Candy-Man possessed chameleonlike qualities. He poses himself as a Suf, telephoning Allah and earning money with the help of such antics."

In the opening lines of the novel, the society is peaceful; all the diverse communities dwell in harmony and do not want the country to be divided. Pandey stated:
Partition's legacy is 'an extraordinary love-hate relationship' bifurcated between 'deep resentment and animosity, and the most militant of nationalism' and 'a considerable sense of nostalgia, frequently articulated in the view that this was a partition of siblings that should never have occurred'. (Pandey, 2001, as cited in Chambers, 2014 p. 2).

Ice-Candy-Man sells frosty, sweet popsicles to children and these popsicles are identical to his temperament. His cool nature symbolizes the harmony and affection that the inhabitants have in their hearts for other communities, as also their willingness to shield their friends from the impending problems. Jagjeet Singh, "If need be, we'll protect our Muslim brothers with our lives" (Sidhwa, 2006, p. 65). Chaudhary declared, "I am prepared to take an oath on the Holy Koran... that every man in this village will guard his Sikh brothers with no regard for his own life!" (Sidhwa, 2006, p. 65). The rapidly changing situation of the nation and the idea of partition now takes a back seat. The British liberate India, but it is about to be divided. This evokes profound worry in the citizens, who are apprehensive about their future. The Ice-Candy-Man now presents a new form, disguising himself as a birdseller. He sits behind the Lahore Gymkhana to attract the English memsahibs with his antics. He coaxes them by threatening the birds: "I break your neck, you naughty birds! You do too much chi chi! What will the good memsahibs think? They'll think I no teach you. You like jungly lions in zoo. 
I cut your throat!" (Sidhwa, 2006, p. 35). When the English women talk to him about his mistreatment of these innocent birds, he says, "Them fresh parrots, memsahib. They do not learn dirty words yet. I catch them today... They only one rupee for two birds" (Sidhwa, 2006, p. 35).

The English memsahibs buy all the birds and free them. The birds in the cages symbolize the subjugated colonized Indians, wanting to be free of British rule. Ice-Candy-Man's dialogues metaphorically unveil the psyche of the Indian people. The guileful Ice-Candy-Man wants the memsahibs to free the birds and for them to realise the importance of freedom, and he probably succeeds. Unfortunately, the British leave India divided. There is a sort of parallel between the Occident (the British) and Dilnawaz, in the sense that the British divide and create a fence through the Orient in the form of the Radcliffe line just as Dilnawaz captures the birds to earn money.

Hindus, Sikhs and Muslims develop negative feelings towards each other. The communities, once united, now start detesting each other. Ayah's group used to visit the Queen's Garden and share their opinions but they develop ill thoughts for other communities and religions. Thus, the Orient-Occident dichotomy can be seen in Indians as well.

The next mask of the Ice-Candy-Man as a prophetic character serves to depict the absurd breakdown of the society and highlights its hypocrisy. He now appears with a trident-shaped iron rod with bells, wearing a long, sleeveless green garment that reaches his hairy calves. He has several different beads hanging around his neck. He shouts "Ya Allah!" (Sidhwa, 2006, p. 106) and addresses God as ' $t u$ ' instead of a respectful word. He covers his upper arms with beads and claims that he can speak to Allah directly through a phone. Some people approach him, saying, "Sufi Sahib, we have four daughters and my wife has a desire of a son." (Sidhwa, 2006, p. 106). He dials the number 786 and pretends to be speaking to God. He instantly produces a spark by connecting the electric wire that covers his neck before responding to them. His ash-smeared face petrifies the children. In this way, he tries to deceive the crowd. The Ice-Candy-Man says, "Wah, Allah... There is no limit to your munificence! To you, king and beggar are the same! Ah! The intoxication of your love! The depth of your compassion! The ocean of your generosity! Ah! The miracle of your cosmos!" (Sidhwa, 2006, p. 108).

We observe that like Ice-Candy-Man, the society too is full of people deceiving other naive citizens. The sparks from the copper wire symbolize the intensity of the frenetic fire blazing in their hearts. The thumping of the trident-shaped iron rod is a dire prognostication of the impending difficulties that the Indian society must be prepared to face. His ornaments, clothes and facial expressions represent the society's hypocrisy; his ash-smeared face hints at the dreadful events that will transpire in the coming future. His exceptional manner of conversation is full of menace and his overall disguise acts as a warning and paints 
a picture of the society during this time. He said, "Haven't you heard her pray?... He's been busy of late... You know; all this Indian independence business." (Sidhwa, 2006, p. 108).

Ice-Candy-Man points out the grim conditions of the nation as he says that no other problem is as significant to God as the partition and He is also very solemn and sad. The hostile partition of the nation is extremely dreadful and all the communities-Hindus, Muslims and Sikhs-suffer brutalities which force them to migrate. Pandey stated,

The violence of 1947 'created new subjects and subject positions.' After Partition families and communities remade themselves in new settings, rebuilt new histories, new identities and new memories. But they have not been able to cast aside the memory of violence and the memory of their prior homeland. (Pandey, as cited in Khan, 2018, pp. 15-16).

The ghost train arrives, and all the Ice-Candy-Man finds are dead bodies. There are two sacks filled with the chopped breasts of women, on seeing which he turns rigid, cold-blooded and vengeful. He takes interest in arson and brutality. The maimed bodies of Muslim women replaced those of Hindu and Sikh women. This dreadful event totally changed his lifestyle. Talking about the atrocities inflicted on women, Hussain (2017, p. 11) said, "The women were not only killed but first tortured, raped and then butchered like animals. Through this event,
Sidhwa questions the hypocrisy of people who glorify the image of the Indian women and worship them as goddesses."

Ice-Candy-Man starts wearing a Jinnah cap, made from the fur of the Karakul breed of sheep and named after Muhammad Ali Jinnah who represents a staunch belief in the Muslim community. Talking about the discussion of Jinnah in Sidhwa's novel, Thakur (2013) emerged that she invoked the image of Jinnah to provide an objective view of Jinnah.

The intensity of his desire for revenge is abundantly clear from his facial expressions. When Ayah (his beloved) and Lenny scream with fear of arson of Hindu colonies, Ice-Candy-Man says, "What small hearts you have... You must make your hearts stout! ... The fucking basterds! They thought they'd drive us out of Bhatti! We've shown them!" (Sidhwa, 2006, p. 147).

In fact, he wishes to show them the violence of the city. His heart was on fire with hatred; he wants to hurt everyone and even unites with the looting rioters who rape Sher Singh's sister. This is in sharp contrast to when, in the pre-partition period, he says to his friend Sher Singh, "I'm first a friend to my friends... And then a Mussalman!" (Sidhwa, 2006, p. 131). A sweet, romantic and amiable man becomes a jealous, devilish so-called 'Allah man' walking the path of staunch Muslims, believing he is serving his God. He thinks he is doing right by his religion because the Taliban is misrepresenting the Koran 
and call themselves Jihadis in Afghanistan. He wants to scare Ayah by showing her the exploding bombs: "I only want her to see the fires. You will see a tamasha." (Sidhwa, 2006, p. 146).

Ayah and Lenny were terrified of Ice-Candy-Man's transformed habits and perilous intentions. Ice-Candy-Man knows of the intimate relationship between Ayah and Masseur. When Ayah rejects IceCandy-Man's proposal, his heart is filled with abhorrence for the both of them and he murders Masseur to exact revenge. Masseur's corpse acts as a perfect reflection of Ice-Candy-Man's hatred because the two men were once friends.

Every time Ayah and Masseur meet, Lenny senses Ice-Candy-Man's presence around them. She said,

Where Masseur is, Ayah is. And where Ayah is, is Ice-Candy-Man. I sense his presence. While Masseur's voice lures Ayah to the dizzy eminence of one minaret, it compels Ice-CandyMan to climb the winding stairs to the other minaret. On the riverbank, I sense his stealthy presence in the tall clumps of pampas grass. He lurks in the dense shade of mangoes in the Shalimar Garden and in the fearsome smells skirting the slaughterhouse... He prowls on the other side of artificial hills behind the zoo lion's cage and conceals himself behind the peacocks when they spread their tail feathers and open their turquoise eyes: he has as many eyes, and they follow us (Sidhwa, 2006, p. 130).
In his study, Purohit observed, "It also attempts to analyze the reasons behind the difference in the perspectives of the male and the female novelists in projecting women as the prime targets and victims of this history of death, destruction, defilement and destitution." (Purohit, 2012, p. 435).

Ayah wishes to go to Amritsar on seeing the deteriorating circumstances around her, but Masseur consoles her, saying:

"You don't need to go anywhere. Why do you worry? I'm here. No one will touch a hair on your head. I don't know why you don't marry me!" To this, Ayah replies, "I'm already yours. I will always be yours." (Sidhwa, 2006, p. 168).

After murdering Masseur, Ice-CandyMan believes he is free to treat Ayah the way he fancies. This incident is Sidhwa's way of showing the victimization, objectification and marginalization of women.

Due to the havoc caused by the partition, there are very few groups left in the park, and the friendship between different communities is as good as dead. Ice-Candy-Man's behaviour, thus, serves to represent the upheavals in society. Tripathi (2015, p. 142) states, "While Sidhwa in Cracking India portrays multiple and playful forms of the desire of the body and the violence on men and women's bodies during the Partition, Mehta's Earth features violence against the bodies within the matrix of nationalist violence."

In the concluding chapters, Ice-CandyMan takes on the most dangerous face of 
the pimp. He trades abducted women at Hira Mandi (kotha) for the aristocrats that visit the brothel and whom the prostitutes entertain with their music and dance. IceCandy-Man assists the Muslim community in abducting his love interest Ayah and taking her away to Hira Mandi where she is raped by multiple men. Talking about Hira Mandi, Chambers said,

The area was originally built as a sanctuary for the illegitimate sons of Moghul emperors and their tawaifs, also known as nautch-girls or courtesans, who during the Raj era at least were mostly Muslim women from North India. The exploitation of women, many of them from the countryside, went hand in hand with an attempt to dress this up in glamorous ways. (Chambers, 2014, p. 9).

Readers are made to wonder why IceCandy-Man waits three months to marry Ayah instead of marrying her right away. He weds Ayah after satisfying himself with vengeance. Ice-Candy-Man comes forward as a terrible lover and a fraud. He wants to appear as though he is doing Ayah a favor by marrying her. People close to Ayah take advantage of her adversities and betray her. At last, Ayah is rescued and sent to the Recovered Women's Camp on Warris Road, but again, Ice-Candy-Man always hovers around the camp. The Sikh guard of the camp threatens and beats them up but he returns, this time in a new disguise - the poet. He recites Zauq: "Why did you make a home in my heart? Inhabit it. Both the house and I are desolate. Am I a thief that your watchman stops me? Tell him, I know this man. He is my face." (Sidhwa, 2006, p. 287).

Ayah wishes to escape the tragic memories of Hira Mandi and of her lover Masseur's brutal murder. Ice-Candy-Man starts selling popsicles again and once, he scatters flower petals in admiration of Ayah. He recites Galib: "My passion has brought me to your street - Where can I now find the strength to take me back?" (Sidhwa, 2006, p. 288). Kleist (2011) said, "I acknowledge that the female characters in Cracking India experience oppression, I assert that they do not operate solely as victims; rather, Sidhwa's women possess distinct forms of power."

Again, he recites Zauq: “Don't betray me, beloved, I'm God-intoxicated! I will wrap myself around you; I'm mystically mad." (Sidhwa, 2006, p. 288). We now see that Ice-Candy-Man is filled with remorse and knows that he will never be able to attain Ayah's attention like before. The fact that he has started selling popsicles again shows that he is trying to distribute sweetness and peace. Ayah is unable to forget her bitter memories of Masseur and Hira Mandi. According to Kumar,

After Partition the line of Control is visible but the pain remains hidden in memory; it is read in the eyes of the victims. We see a different side of IceCandy-Man's character, postcolonial social hitches and the trauma faced by women and created by the anarchy that ensued as a result of the partition. (Kumar, 2018, p. 285). 
Praising Sidhwa's characters, Hajiyeva said,

Bapsi Sidhwa's characters in this regard, usually come from a different cultural background, she also tries to explore women's position in multicultural societies where they face double pressure, who are regarded not as part of events but as symbols on which violence is acted and her position as a multicultural writer enables her to explore these issues from a neutral and more objective point of view. (Hajiyeva, 2016 , p. 141).

According to Chambers (2014, p. 11), "Personifying the city as a fading but still attractive, somewhat tawdry figure, she evokes Lahore's loss of its multicultural identity after partition, which is also reflected in Cracking India."

When a country undergoes a partition, not only one but both the sides are on the receiving end of the pain of separation, dislocation and the quest for identity. We fight for our borders even today, but we do not know how long this chain will continue. We need to draw inspiration and learn from important writings. Cracking India proves that war never has a happy ending for a nation; it is merely the beginning of countless difficulties.

\section{FINDINGS AND DISCUSSIONS}

This study is based on the transformation of the protagonist, Ice-Candy-Man, which symbolizes the societal circumstances of the partition period in Sidhwa's masterpiece Cracking India. The findings of this study are noteworthy as it highlights that war and partition are detrimental to societal peace and harmony. Sidhwa focuses on the brutal and vicious actions of the characters, predominantly the character of Ice-CandyMan. His character shows his deep trauma through the various transformations his personality goes through over the course of the novel. His trauma was caused by the mounting social crisis and constantly changing society during the partition of India.

Events like this can lead people to undergo temperament-related transformations. Ice-Candy-Man changes from a friendly, jolly fellow to a wicked, immoral one, and we see his virtuousness change into crookedness. Human nature is such that one never wants to leave one's relatives and the land of one's forefathers. The above study unzipped the portrayal of atrocities on the women of the partition periods. The interpretation of 'Kotha' or 'Hira Mandi' focuses on the weird mentality of the people who understand a woman a source of their entertainment. Women suffered many hitches during the partition because she is known as the creator of the new generation in this world. According to the critical-thinking of the chaotic element, if they eliminate women, a new generation will destroy itself, that was done on both sides. Bapsi Sidhwa went through this agony and suffering in childhood, forcing him to study the novel. According to Din (2010), "Ice Candy Man truly reflects how the child narrator (Lenny) perceives the world around her and is haunted by the psychological 
outbursts of the brutality of the events". (p. 208).

According to Sarkar "In Mourning the Nation (2009), Bhaskar Sarkar speaks of a "proleptic melancholia" of the nation. The postcolonial nation is born in loss, he argues. It represents "the death of a collective dream at the moment of birth." (Sarkar, 2009, as cited in Mitra, 2015, p. 134). Throughout this study, we have worked with psychoanalytical and postcolonial perspectives.

\section{CONCLUSION}

This study analyzes the character of IceCandy-Man. Each entry of Ice-CandyMan with a new personality was full of suspense and takes the premise forward, showing the different aspects of the everchanging society. Through the character of Ice-Candy-Man, Sidhwa portrays the agony Indians faced during the partition. $\mathrm{He}$ is also a portrayal of untrustworthy statesmen who are self-centric and do not care for the nation's betterment. Kumar (2014, p. 148) said, "Ice Candy Man gives us a glimpse into the events of turmoil on the Indian subcontinent during Partition." His brutal personality is the outcome of the tumultuous times India has seen. Hence, through Ice-Candy-Man, Sidhwa shows the changing patterns of communal discord. The author shows how Ice-Candy-Man's trauma impacts him and how it is reflected in his actions. He uses crude language, and rebels against social norms. Ice-Candy-Man is opportunistic, accumulating power and fame through his repeated incarcerations.
He is indisputably a symbolic representation of the disturbing circumstances of society.

Thus, I should say that Sidhwa's roguish and fascinating character Ice-Candy-Man is an everlasting companion of the readers and illuminates this novel.

\section{ACKNOWLEDGEMENT}

Authors are highly thankful to the Head of Department of Languages, Manipal University Jaipur, India for providing the necessary facilities for carrying out this research work. We are also highly grateful to the reviewers for their valuable reviews on the manuscript and extremely thankful to Dr. Sudhi Rajiv, Former Dean, Professor and Head of Department of English, Jai Narain Vyas University, Jodhpur, India for polishing the manuscript for grounding the final submission.

\section{REFERENCES}

Banerjee, S. (2015). Theme of pseudo-neutrality in Bapsi Sidhwa's Ice-Candy-Man. Labyrinth, The Bi-Annual Literary Journal of Postmodern, 2(1), 142-147.

Banyard, L. V. (2000). Trauma and memory. PTSD Research Quarterly, 11(4), 1-6.

Bhaskar, M. T. (2015). Bapsi Sidhwa's Ice-CandyMan: A thematic study. International Journal of Arts, Humanities and Management Studies (IJAHMS), 01(7), 55-60.

Butalia, U. (1998). The other side of silence. Gurgaon, India: Penguin Random House.

Chambers, C. (2014). The heart, stomach and backbone of Pakistan: Lahore in novels by Bapsi Sidhwa and Mohsin Hamid. South Asian Diaspora, 6(2), 141-159. doi: 10.1080/19438192.2014.912463 
Din, U. U. (2010). Reflection on partition literature A comparative analysis of Ice-Candy-Man and Train to Pakistan. Language in India Strength for Today and Bright Hope for Tomorrow, 10, 196-209.

Gautam, S. R. (2015). Child as narrator in Cracking India. International Journal of English Language, Literature and Humanities, IJELLH, 3(7), 517-527.

Hajiyeva, M. (2016). Pakistani English literature in multicultural context. Journal of Research (Humanities), 5(LII), 133-144.

Hunt, N. (2010). Personal narrative and social discourse. In Memory, War and Trauma (pp. 6180). Cambridge, England: Cambridge University Press. doi: 10.1017/CBO9780511845017.006

Hussain, B. I. (2017). Bapsi Sidhwa's novel IceCandy-Man: A feminist perspective. Internal Journal of English Language and Humanities, (IJELLH), 5(11), 1-8. Retrieved October 10, 2020, from https:/www.ijellh.com/OJS/index. php/OJS/article/view/2515

Islam, S. (2018). Muslims against partition of India. New Delhi, India: Pharos Media \& Publishing Pvt. Ltd.

Khan, N. (2018). Displacement, memory and historical continuity in Intizar Hussain's Basti. In S. M. Y. Ibrahim (Ed.), Remapping history and (con)textualizing literature (pp. 126-132). New Delhi, India: Authors Press.

Kleist, J. M. (2011). More than victims: Versions of feminine power in Bapsi Sidhwa's Cracking India. Pakistaniaat: A Journal of Pakistan Study, 3(2), 144.

Kumar, P. A. (2014). Postcolonial perspectives on partition: A study of Bapsi Sidhwa's Ice-CandyMan (Cracking India). An International Literary Journal (LLILJ), 4(2), 137-149.

Kumar, Y. (2018). Partition as memory: (Con) textualizing Maheep Singh's Pani Aur Pul. In
S. M. Y. Ibrahim (Ed.), Remapping history and (con)textualizing literature (pp. 284-288.). New Delhi, India: Authors Press.

Majid, A., \& Hamid, Z. A. (2014). Genesis of the two nations theory and Quaid-e-Azam. Pakistan Vision Academic Journal, 15(1), 180-192.

McLeod, S. A. (2019, April 10). Defense mechanisms. Simply psychology. Retrieved October 30, 2020, from https://www.simplypsychology.org/ defense-mechanisms.html

Misra, R. (2018). Citizenship in dispute: The case of outmigrants from Barpeta, Assam. Economic and Political Weekly, 53, 20-22.

Mitra, R. (2015). States of affects: Trauma in partition/ post partition South Asia (Doctoral dissertation, Michigan State University, USA). Retrieved October 10, 2020, from https://d.lib.msu.edu/islandora/object/etd:3433/ datastream/OBJ/download/STATES_OF_ AFFECT___TRAUMA_IN_PARTITION_ POST-PARTITION_SOUTH_ASIA.pdf

Pandey, M. (2003). Feminism in contemporary British and Indian fiction. Delhi, India: Sarup and Sons.

Phogat, G., \& Attri, S. (2013). Acceptance/existence: A postcolonial study of Bapsi Sidhwa's IceCandy-Man (Cracking India). Periodic Research, 2(1), 144-146.

Purohit, R. (2012). An androcentric and gynocentric perspective of women as victims in partition fiction: A comparative study. Language in India Strength for Today and Bright Hope for Tomorrow, 12(2), 443-471.

Roy, R. (2010). South Asian partition fiction in English from Khuswant Singh to Amitav Ghosh. Amsterdam, Netherlands: Amsterdam University Press.

Sidhwa, B. (2006). Cracking India. Minnesota, USA: Milkweed Edition.

Shah, A. J. (2018). The legacy of partition. In S. M. Y. Ibrahim (Ed.), Remapping history and (con) 
textualizing literature (pp. 149-153) New Delhi, Tripathi, A. (2015). Transaction from inscription to India: Authors Press.

Sreenivas, M. (2017). India Pakistan Partition. Origins: Current events in historical perspective. Retrieved October 30, 2020, from http://origins. osu.edu/milestones/december-2017-indiapakistan-partition

Thakur, S. (2013). Cracking India: Rewriting of visual: A study of Bapsi Sidhwa's Cracking India and Deepa Mehta's Earth. International Journal of English Language, Literature and Translation Studies (IJELR), 2(5), 142-147.

Visser, I. (2011). Trauma theory and postcolonial literary studies. Journal of Postcolonial Writing, 47(3), 270-282. doi: 10.1080/17449855.2011.569378 history by a Parsi woman. International Journal of the Frontiers of English Literature \& The Patterns of ELT, 1(2), 1-13. 
